\title{
Farm management decision and response to climate variability and change in Côte d'Ivoire
}

\author{
Hermann Comoé • Robert Finger • Dominique Barjolle
}

Received: 28 June 2012 / Accepted: 5 November 2012 /Published online: 14 November 2012

(C) Springer Science+Business Media Dordrecht 2012

\begin{abstract}
This paper investigates threats to farm management in the northern and central region of Côte d'Ivoire, with a particular focus on climate-related threats. To this end, farmers' perception and adaptation strategies for climate change have been analyzed. The data were collected from 205 respondents by means of the Focus Groups method, and they were evaluated using a framework analysis. The main reported threats related to the implementation of farming activities are the high cost of inputs and the lack of technical support, which are followed by diseases, insects, and climate variations (scarcity of rains, strong winds, and high temperature). We find that most farmers have a strong perception of changes in climatic conditions. Their perceived impacts on the local environment through evidences like the disappearance of certain farming practices, occurrence of new insects, and the disruption of key time reference periods. Farmers mainly attempt to adapt by adjusting their agricultural calendar, adopting new short-season varieties, and using mixed cropping. We find that the most influential factors for farmers' adaptation behavior is lack of contact with extension services and the scarcity of rainfall. Our suggestions for future agricultural policies for better adaptation to climate change are to take into account farmers' perception, to provide suitable climate forecast, and to improve local technical support.
\end{abstract}

Keywords Adaptation strategies · Agriculture Climate change $\cdot$ Côte d'Ivoire Perception $\cdot$ Smallholder farmers

H. Comoé $(\bowtie) \cdot$ D. Barjolle

Institute for Environmental Decisions IED, Agri-Food and Agri-Environmental Economics Group, ETH Zürich, Sonneggstrasse 33, 8092 Zürich, Switzerland e-mail: hecomoe@ethz.ch

D. Barjolle

e-mail: barjolle@ethz.ch

R. Finger

Agricultural Economics and Rural Policy Group, Wageningen University,

Hollandseweg 1, $6706 \mathrm{KN}$ Wageningen, The Netherlands

e-mail: robert.finger@wur.nl 


\section{Introduction}

Climate change (CC) according to the United Nations Intergovernmental Panel on Climate Change (IPCC), refers to any change in climate over time, whether due to natural variability or as a result of human activity. Climate variability refers to variations in the mean state and other statistical measures (such as standard deviations and statistics of extremes) of the climate on all temporal and spatial scales beyond that of individual weather events (IPCC 2007). Unless formal distinctions between CC and climate variability are drawn, CC itself becomes a difficult concept to define, because all natural "change" is merely a reflection of variability on some appropriate time scale (Washington et al. 2006). CC and climate variability are not conveniently separated processes, but are instead closely coupled in the complicated evolution of the climate system.

In West Africa, the impact of CC is expected to be very severe because it directly causes damage to domestic welfare, which depends mostly on the primary sector of the economy (Mendelsohn et al. 2000). During the last decades, CC has been very evident and has resulted in a southward shift of the climate zones, e.g., spread of the Sahara desert into the Sahelian zone (Wittig et al. 2007). A decline in annual rainfall has been observed since the end of the 1960s, with a decrease of 20-40\% noted between the periods 1931-1960 and 1968-1990 (Nicholson 2000; Chappell and Agnew 2004). As a prevision, it is foreseen that the crop yields will be adversely affected and the frequency of extreme weather events will increase (Collier et al. 2008). The projected reductions in yield could rise up to $50 \%$ by 2020 , and net crop revenues could fall down to $90 \%$ by 2100 , with small-scale farmers being the most affected (Boko et al. 2007).

Adaptation is defined as the "adjustment in natural or human systems in response to actual or expected climatic stimuli or their effects, which moderates harm or exploits beneficial opportunities" (IPCC 2007). Although CC is a difficult phenomenon to detect according to some authors (Blennow and Persson 2009; Elke 2010), farmers in Sub-Saharan Africa are well aware of CC (Benedicta et al. 2010). In particular, subsistence farmers are far more likely to notice changes in climate than other farmers because of their experience in farming (de Wit 2006). The fact that farmers are very good at detecting CC is a basic precondition for adaptation (Maddison 2006). Despite this fact, many African farmers have done almost nothing in response to CC (Ringler 2010). To overcome this gap in implementing adaptation strategies, it is essential to understand farmers' behavior in their decisionmaking with regard to climate risks, in order to establish efficient and acceptable adaptation strategies for CC.

Like most developing countries in Western Africa, Côte d'Ivoire is vulnerable to CC, specifically in the sectors of agriculture, coastal resources, water resources, and forestry (MEEF 2000; Ochou 2011). This vulnerability is exacerbated by widespread poverty, environmental degradation, natural resource mismanagement, and dependence on rain-fed agriculture (Dixon et al. 2003). The temperatures increased approximately by $1{ }^{\circ} \mathrm{C}$ between 1960 and 2000 (Kouakou et al. 2012), and annual rainfall decreased by an average of $0.5 \%$ per year between 1965 and 1980 and by $4.6 \%$ per year in the 1980s (MET 1994; Birgit and Bruzon 2006). The impacts of CC are gradual in the South of the country, but are already significant in the North (Gadegbeku 2009).

Based on this background, we aim to investigate how farmers in two regions of Côte d'Ivoire-Toumodi in the central part and Korhogo in the North-have perceived as well as reacted to these changes. More specifically, this paper intends to (i) identify farmers' decisions regarding farm management in general and more specifically regarding actions for adapting to $\mathrm{CC}$; (ii) assess their perception of $\mathrm{CC}$; and (iii) identify influencing factors for 
their adaptation behavior. This first study of its type in Côte d'Ivoire will provide useful insight into farmers' decision-making processes regarding adaptation to CC.

\section{Study areas}

The climate in Côte d'Ivoire is generally warm and humid and is overall transitional from equatorial to tropical (Fig. 1). Toumodi is located in the forest-savanna transition zone of central Côte d'Ivoire and has two rainy seasons; the average annual rainfall is 1,000$1,200 \mathrm{~mm}$ and the temperature ranges between $14{ }^{\circ} \mathrm{C}$ and $39{ }^{\circ} \mathrm{C}(\mathrm{MPARH} 2003$; Tié et al. 2010). The soil is characterized by sandy-humus and clayey horizons (Birgit and Bruzon 2006). The climate in Korhogo (North) is Sudano-Guinean with a single rainy season and annual rainfall between 1,100 and $1,600 \mathrm{~mm}$. The temperature ranges between $10{ }^{\circ} \mathrm{C}$ and $42{ }^{\circ} \mathrm{C}$ (MPARH 2003). Generally, the soil in Korhogo is ferruginous with low humus content and average fertility (Zagbaï et al. 2006). The central and northern areas are different with regard to both their vegetation and socio-cultural characteristics. Therefore, the results of the study could help understand the importance of these socio-cultural factors in farmers' decision-making behavior regarding adaptation to $\mathrm{CC}$.

\section{Methodology}

This study used a qualitative research method because the purpose is to develop an in-depth understanding of farmers' perception of and their adaptation behavior regarding adaptation to $\mathrm{CC}$. The collected qualitative data allow us to identify in an exhaustive manner all factors influencing farmers' behavior.

\subsection{Focus groups}

Focus Groups is a method for collecting data through group interaction on a topic determined by the researcher (Morgan 1997). This method has been developed and applied since the 1990s (for more details see Krueger 1994; Templeton 1994; Morgan and Krueger 1998). One of the key advantages of Focus Groups is its flexibility and ability to reveal rich and sensitive information. One of the limitations of Focus Groups is that it can result in an undesirable bias: first, the moderator could exert too big an influence on the group; second, the phenomenon of dominance may occur (some participants may strongly influence the discussion). To avoid these biases, we developed precise guidelines and trained the moderator on how to deal with group interactions and dominant participants.

We have chosen this approach because it is ideal for exploring the complexity surrounding farmer's adaptation behavior regarding climate variability and change, and can generate large amounts of data in a relatively short time span; moreover, the findings may be used as preliminary data for quantitative procedures (Rabiee 2004).

The questions discussed were tailored around guidelines related to the following four topics: (i) Farmers' farm management and opportunities, including farmers' aims regarding farm management, the relevant threats, and implemented actions; (ii) Farmers' perception of $\mathrm{CC}$ through atmospheric characteristics, farming practices, and local environment; (iii) The way farmers deal with climate uncertainties, especially the sources and types of information they receive; (iv) Factors influencing farmers' behavior related to adaptation to CC. Therefore, their past experiences, knowledge, and expectation with regard to $\mathrm{CC}$ were 


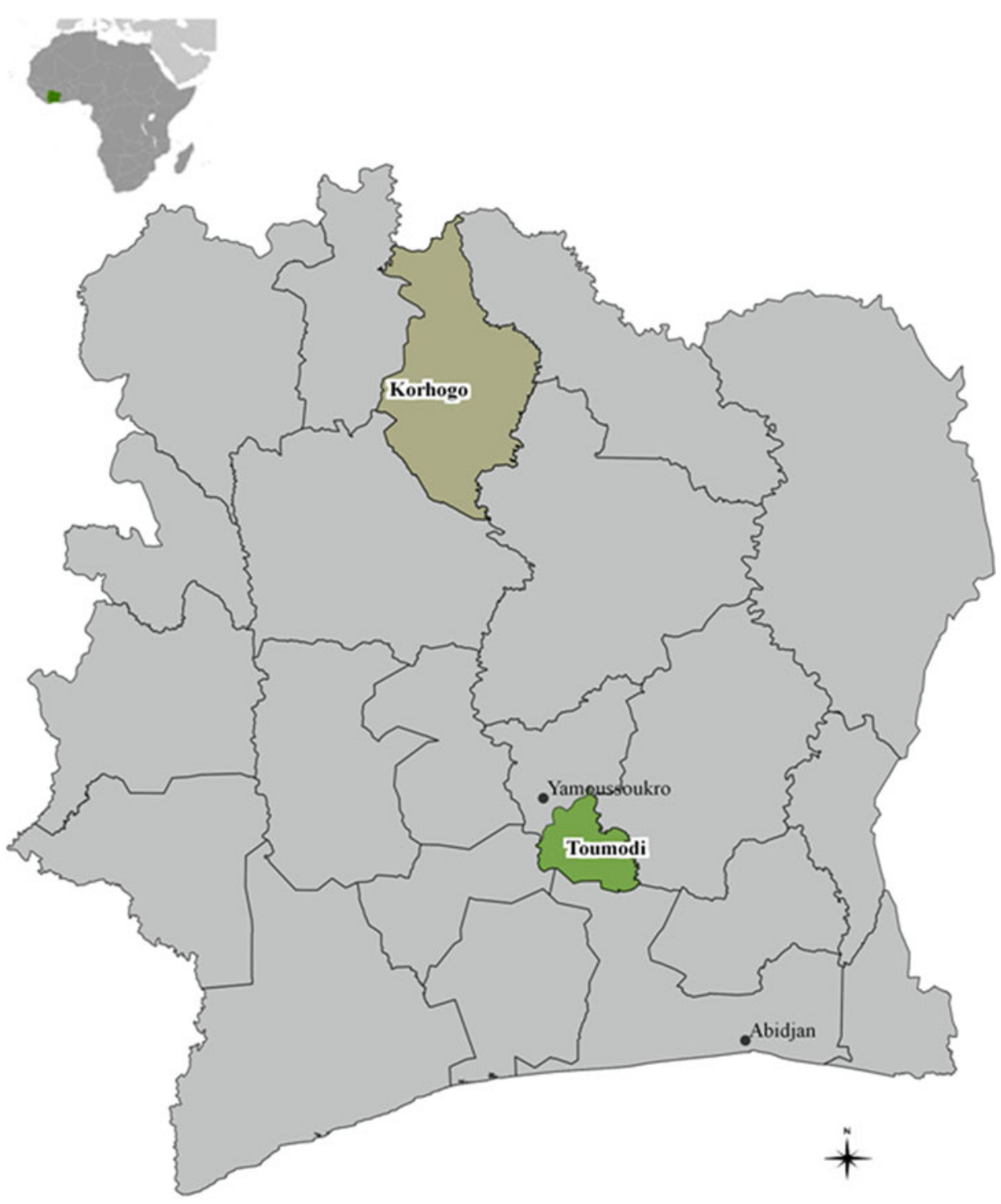

Fig. 1 Côte d'Ivoire study areas

discussed. Finally, the conflicts between crop and livestock farmers and their probable link with CC have also been discussed (e.g., damage to growing crops, destruction of harvest, and pressures on the fallow imposed by herds) (Hussein et al. 1999).

\subsection{Sample selection and description}

Sixteen Focus Groups investigations were carried out from June to August 2011 in Toumodi ( 8 in 9 villages) and Korhogo ( 8 in 4 villages), with a total of 205 respondents which represents $4 \%$ and $0.8 \%$ of all farming households in Toumodi and Korhogo, respectively. We followed the method of Krueger (1994) by continuing with the Focus Groups until a 
clear pattern emerged and subsequent groups produced only repetitious information (theoretical saturation). The resulting sample size is comparable to that of other studies which used the Focus Group approach (cp. e.g. Zaouche et al. 2011; Ishak and Bakar 2012). The information gathered in our Focus Groups was exhaustive, which was underlined by the finding that the last additional group discussion did not reveal any new item.

The ideal number of participants in a group ranges from six to ten (Zaouche et al. 2011). To build up our sample, we considered (i) the geographical location of the village, (ii) the type of farming activities, and (iii) the age of the farmer as the main selection criteria.

First, in Toumodi, the villages were randomly selected using a list of farmers obtained from the National Rural Development Support Agency (ANADER); villages in both in the forest and the savannah parts were selected, after ruling out those inaccessible by car. In Korhogo, the same process was used.

Secondly, participants in the Focus Groups were selected so that different farming activities were represented: we therefore selected crop farmers, livestock farmers, and those involved in diversified farming. Finally, elderly participants with maximum age about 80 years were selected because they had experienced a change in climatic elements over the past 30-40 years. This sampling approach allows researchers to compare the views of different types of farmers and to better understand the factors leading to the implementation of the strategies being practiced. The socio-cultural differences between the two areas were considered. In Korhogo (Muslim and conservative part of the country), women and men were separately interviewed, which was not the case in Toumodi.

The discussions were recorded and were conducted with the support of local extension agents and students who also translated the local languages Baoulé, Sénoufo, and Dioula to French. To avoid misinterpretation during the transcription, two agents worked together throughout all Focus Groups discussions. Furthermore, the geographical coordinates of villages, socio-demographic characteristics, and data related to the surface of farms, the type of crop grown, and the number of animals was collected.

The average age of the participants was 45 years, and the average household size was 10 people. The level of education in Korhogo is much lower than that in Toumodi. Moreover, the average number of years of experience in crop farming and livestock production was 22.32 years and 10.20 years respectively (Table 1). The Mann-Whitney $U$ test (Field 2009) applied to the sample revealed significant differences between farmers with regard to crop farming experience, gender, education level, head of household status, and marital status.

\subsection{Data analysis}

The framework analysis as described by Ritchie and Spencer (1994) was used to analyze the 300 pages of transcribed notes. It involved five highly interconnected key stages: familiarization; identifying a thematic framework; indexing; charting; and mapping and interpretation. Familiarization can be achieved by listening to recorded discussions and notes and reading the transcript several times. This is followed by identification of a thematic framework by writing memos in the form of short phrases and ideas, and beginning to develop categories. Indexing involves sifting the data, highlighting and sorting out quotes, and making comparisons both within and between groups. Charting involves lifting the quotes from their original context 
Table 1 Characteristics of the farmer participants in the Focus Groups

\begin{tabular}{|c|c|c|c|}
\hline & Variable & Korhogo & Toumodi \\
\hline \multirow{9}{*}{ Education level*** } & Age (year) & $45.85(15.26)$ & $46.98(13.37)$ \\
\hline & Household size & $11.14(7.12)$ & $10.59(5.85)$ \\
\hline & Household head $(\%)$ & $61.5 * *$ & 81.2 \\
\hline & Male $(\%)$ & $54 * * *$ & 85 \\
\hline & Illiterate $(\%)$ & 83.7 & 39.6 \\
\hline & Primary school (\%) & 13.5 & 32.7 \\
\hline & Secondary school (\%) & 1.9 & 23.8 \\
\hline & University (\%) & 0 & 4 \\
\hline & Koranic school (\%) & 1 & 0 \\
\hline \multirow[t]{12}{*}{ Marital status*** } & Single $(\%)$ & 1.9 & 22.8 \\
\hline & Married (\%) & 90.4 & 74.3 \\
\hline & Widower/Widow (\%) & 7.7 & 2 \\
\hline & Divorced (\%) & 0 & 1 \\
\hline & Experience in crop farming (year) & $22.32 * *(14.32)$ & $15.26(10.06)$ \\
\hline & Experience in livestock practicing (year) & $10.20 * * *(10.28)$ & $7.2(5.69)$ \\
\hline & Surface of root, tuber \& starchy (ha) & $0.12 * * *(0.36)$ & $1.55(1.58)$ \\
\hline & Surface of cereal (ha) & $2.72 * * *(2.6)$ & $0.16(0.35)$ \\
\hline & Surface of vegetable (ha) & $0.13(0.29)$ & $0.19(0.47)$ \\
\hline & Surface of cash crops (ha) & $4.87(5.53)$ & $3.25(3.83)$ \\
\hline & Number of ruminant and porcine & $6.76 * * *(11.78)$ & $2(8.18)$ \\
\hline & Number of poultry & $5.08(10.65)$ & $5.55(14.36)$ \\
\hline
\end{tabular}

Numbers in parentheses are standard deviations. *** and ** denote significance on the $1 \%$ and $5 \%$ level

and re-arranging them under the newly-developed thematic content. The coded data can be interpreted based on words, context, internal consistency, frequency, and extensiveness of comments (Krueger 1994). In qualitative analysis, coding the processes of identifying and connecting the passages of text and clarifying the concept or idea represented by the "node" is an important part of the analytic process.

A node (or item) is defined as a group of words, and sentences of the transcript, which are related to the same topic or subject. It could be sub-divided into small parts called sub-nodes which contain more focused information.

For this study, the frequencies of the number of quoted words or sentences are assigned to different nodes, which indicates its relative importance to other nodes. The score helps build up adequate and nuanced conclusions (Paillé 1996). As a requirement for reliability, an inter-coder was also used to establish dependability of the data analysis. The software N'vivo 9 was used to organize, code, and classify the transcript (www.qsinternational.com/products_nvivo.aspx). The total number of nodes (equivalent to items) created for Toumodi and Korhogo was 108 and 106 respectively, grouped into 12 main nodes (Table 2), which covered $48 \%$ and $46 \%$ of the transcript respectively. The most represented nodes were "relevant threats in farm management," "adaptation strategies to CC," and "perception of CC." The similarity in both study areas reveals the common interests of farmers with regard to the most frequent items. 
Table 2 Frequencies of most items quoted by farmers ( $\%$ of words and sentences)

\begin{tabular}{lll}
\hline Item & $\begin{array}{l}\text { Korhogo } \\
\text { Frequency (\%) }\end{array}$ & $\begin{array}{l}\text { Toumodi } \\
\text { Frequency (\%) }\end{array}$ \\
\hline Relevant threats & 10.82 & 9.78 \\
Adaptation strategies to CC & 8.59 & 8.23 \\
Perception of CC & 7.75 & 8.76 \\
Causes of CC & 4.95 & 3.06 \\
Impacts of CC & 4.94 & 4.97 \\
Suggestions for adaptation & 3.26 & 1.93 \\
Actions implemented against threats & 2.93 & 1.95 \\
Own objectives of farmers & 2.34 & 3.14 \\
Conflicts between crop \& livestock farmers & 1.31 & 2.27 \\
Opportunities in farm management & 0.77 & 0.53 \\
Knowledge about weather \& CC forecasting & 0.50 & 1.34 \\
Farmers' pessimistic expectations & 0.12 & 0.43 \\
Total & 48.28 & 46.39 \\
Standard deviation & 3.48 & 3.30 \\
\hline
\end{tabular}

The total does not equal 100 because all the 300 pages of transcript were not embedded into a node, notably the intervention of the moderator of the discussions

\section{Results and discussion}

\subsection{Farmers' perception of relevant threats in farm management}

The relevant threats of farmers have been grouped into seven categories (Table 3). The analysis of the Focus Groups showed that the threats related to the technical farming factors are the most relevant for farmers in both study areas. This category includes the following items stated by the farmers: high cost of inputs (pesticides, herbicides, and fertilizers), financial problems, rapid growth of weeds, non-effectiveness of certain treatments against insects and weeds, poor quality of seeds, lack and high cost of farming labor, coincidence of farming activities, wildfire, and large fields compared to the low availability of household labor. The major threats related to the technical farming factors differ across study regions. In Toumodi, the most important threats are insects and diseases, followed by climate (unpredictability of climate and scarcity of rains) and farming lands (lack of farming lands and poor soil fertility), and finally lack of technical support. In Korhogo, the major threats mentioned by farmers, in order of the biggest threat to the smallest, are market access and prices, insects and diseases, and climate and animal breeding. These differences are due to differences in farming systems (e.g., the use of different crops and the focus on livestock breeding in Korhogo) and location (Toumodi is closer to the main market in Abidjan).

\subsection{Farmers' perception of climate change}

In Korhogo, the following indicators are most frequently used by farmers to describe their perception of $\mathrm{CC}$ : changes and characteristics in rains patterns, changes in the local environment, and disappearance of some farming practices. Thus, indicators such as sunshine, wind characteristics, disturbance of farming seasons, and reference period are less 
Table 3 Description of relevant threats in farm management

\begin{tabular}{|c|c|c|c|c|c|}
\hline \multirow[t]{2}{*}{ Domain } & \multirow[t]{2}{*}{ Relevant threats in farm management } & \multicolumn{2}{|l|}{ Toumodi } & \multicolumn{2}{|l|}{ Korhogo } \\
\hline & & Quotation & $\%$ & Quotation & $\%$ \\
\hline \multirow{9}{*}{$\begin{array}{l}\text { Technical farming } \\
\text { factors }\end{array}$} & High cost of pesticides, herbicides \& fertilizers & 10 & 4.17 & 48 & 15 \\
\hline & Financial problems & 36 & 15 & 15 & 4.69 \\
\hline & Rapid growth of weeds & 12 & 5 & 15 & 4.69 \\
\hline & $\begin{array}{l}\text { Non effectiveness of pesticides and herbicides } \\
\text { treatments }\end{array}$ & 7 & 2.92 & 8 & 2.5 \\
\hline & Poor quality of seeds & 6 & 2.5 & 7 & 2.19 \\
\hline & Lack \& high cost of farming labor & 12 & 5 & 0 & 0 \\
\hline & Coincidence of farming activities & 7 & 2.92 & 0 & 0 \\
\hline & Wildfire, bushfire & 3 & 1.25 & 1 & 0.31 \\
\hline & Too large fields & 0 & 0 & 1 & 0.31 \\
\hline \multirow[t]{3}{*}{ Insects \& diseases } & Insects and diseases & 30 & 12.5 & 21 & 6.56 \\
\hline & Termites in the soil & 4 & 1.67 & 2 & 0.63 \\
\hline & Animal diseases & 4 & 1.67 & 29 & 9.06 \\
\hline \multirow[t]{6}{*}{ Climate } & Unpredictability of climate & 5 & 2.08 & 0 & 0 \\
\hline & Scarcity of rains & 19 & 7.92 & 23 & 7.19 \\
\hline & Wind & 2 & 0.83 & 0 & 0 \\
\hline & Burning sun & 2 & 0.83 & 0 & 0 \\
\hline & Scarcity of irrigation & 3 & 1.25 & 9 & 2.81 \\
\hline & No dams and rivers & 1 & 0.42 & 9 & 2.81 \\
\hline \multirow[t]{4}{*}{ Farming lands } & Lack \& aging of arable land & 0 & 0 & 15 & 4.69 \\
\hline & Problem of soil fertility & 15 & 6.25 & 3 & 0.94 \\
\hline & Lack of forest & 10 & 4.17 & 0 & 0 \\
\hline & Logging companies & 2 & 0.83 & 0 & 0 \\
\hline Technical support & Lack of technical support & 26 & 10.83 & 22 & 6.88 \\
\hline $\begin{array}{l}\text { Market access \& } \\
\text { prices }\end{array}$ & Market access and low prices & 15 & 6.25 & 56 & 17.5 \\
\hline \multirow[t]{6}{*}{ Animal } & Animal damages & 3 & 1.25 & 21 & 6.56 \\
\hline & Theft of animals \& accident with cars & 4 & 1.67 & 3 & 0.94 \\
\hline & Lack of pasture & 1 & 0.42 & 0 & 0 \\
\hline & No enclosure \& hen house & 1 & 0.42 & 12 & 3.75 \\
\hline & Total & 240 & 100 & 320 & 100 \\
\hline & Standard deviation & 9.35 & 3.90 & 14.45 & 4.52 \\
\hline
\end{tabular}

Focus Groups

frequently mentioned. Furthermore, compared to the farmers in Korhogo, the farmers in Toumodi perceive more intensively the impact of the disruption of key time reference period and shift in rainy seasons (Fig. 2).

\subsubsection{Rain patterns and characteristics}

Farmers have observed a decrease in the frequency and amount of rain. In these areas, rainfalls usually occur at intervals of a few weeks even during the rainy season, and they are 


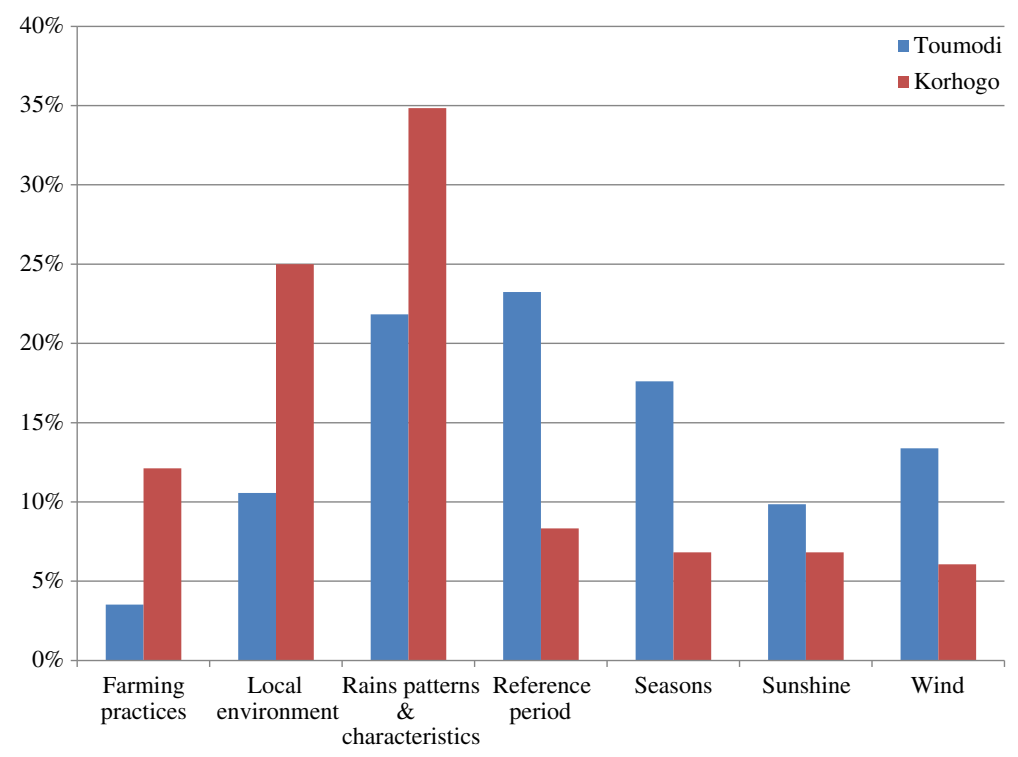

Fig. 2 Farmers' perception of changes in climate

accompanied by thunder and followed by violent winds. The intensity of rainfalls is low, and farmers even find hail after the rain. A change in the spatial distribution of rains has been observed. Also, the rainfalls are now more intense, which sometimes causes crop damage.

The changes observed in the local environment were also used by farmers to describe their perception of climate variability and change. For instance, water does not remain for a long time in shallow ponds during the dry periods anymore. Also, their forecast of rains based on the sunshine does not seem reliable; they used to consider the presence of a lot of stars in the sky at night to indicate upcoming rains, which is not a reliable indicator anymore. Therefore, farmers are not able to properly define the rainy periods. Moreover, current proliferation of unknown pests of crops and a change in fructification time have been noticed.

\subsubsection{Seasons}

It was observed that seasons have shifted and shortened. For instance, in Toumodi, the short dry season which started in August has shifted to July. In addition, farmers mentioned that the rainy seasons have become shorter over time. In the past, it would sometimes rain in the dry season, but this does not occur anymore. These assertions are confirmed by the findings of Goula et al. (2010), who reported that the duration of the growing season decreased by 30 days in the period 1951-2000. Along these lines, Ochou (2011) also attested to higher fluctuations in the end and start dates of the growing seasons.

Farmers explained changes in climate by modifications in their agricultural activities. The disruption of the agricultural calendar is proof of climate variability and change. Farmers mentioned that current onset and cessation times of the rains do not coincide with the times in their previous agricultural calendar. Consequently, they are confused about regularizing their cropping calendar and determining the most suitable crops to cultivate. The technique of crop succession and the semi-direct seeding of 
some crops such as cocoa (Theobroma cacao) are not suitable anymore to the new climatic conditions. Also, farming activities have become more sensitive to even little delays in their implementation.

Certain specific months and dates are considered as key reference indicators of climate over the years. As soon as a change occurs in these time points, farmers associate it as evidence of changes in climate. In Korhogo, August was formerly perceived as a rainy month, with rainfall levels of up to $400 \mathrm{~mm}$ (Beaudou and Sayol 1980). Farmers mentioned that this is no longer the case: i.e., August is currently not perceived as a rainy month. This perception of farmers is confirmed by data from the database of the National Meteorological Office of Côte d'Ivoire (SODEXAM), which show a decrease of $228 \mathrm{~m}$ in August rainfall levels in the period 1971-2002. Furthermore, rainfalls now occur in August instead of July

Table 4 Description of farmers' perception of climate change through non-climatic indicators in Toumodi

\begin{tabular}{|c|c|c|}
\hline Level & Sub-level & Description \\
\hline \multirow[t]{5}{*}{ Agriculture } & Farming seasons & $\begin{array}{l}\text { In the past, the rainy season was the longest. The difference } \\
\text { between the two was small, as it rained sometimes in } \\
\text { the dry season. The short dry season, which is a period } \\
\text { of wind, occurred in August but has shifted to July. }\end{array}$ \\
\hline & \multirow[t]{4}{*}{ Farming practices } & $\begin{array}{l}\text { In the past, farmers practiced the semi-direct seeding of cocoa, } \\
\text { but nowadays they make seedbeds. }\end{array}$ \\
\hline & & $\begin{array}{l}\text { Crop succession was possible, as rains before the harvest } \\
\text { of yam (Dioscorea alata) allowed farmers to sow maize } \\
\text { in the hillocks of yam. }\end{array}$ \\
\hline & & $\begin{array}{l}\text { Nowadays, any little delay in the implementation of farming } \\
\text { activities leads to significant loss in harvest. }\end{array}$ \\
\hline & & The wild animals destroy much more crop. \\
\hline \multirow[t]{4}{*}{ Environment } & \multirow[t]{4}{*}{ Local environment } & $\begin{array}{l}\text { In the past, it was possible to pick up some small pieces } \\
\text { of ice when it rained, but it does not happen anymore. The } \\
\text { weather is colder in the rainy season than before. }\end{array}$ \\
\hline & & $\begin{array}{l}\text { Fruit maturation has changed as evidenced in the case of some } \\
\text { fruits, which are mature on one side and still green on the other. } \\
\text { Other fruits contain a lot of chenille. There is also green moss } \\
\text { on the leaves of mango trees, which did not occur so much before. }\end{array}$ \\
\hline & & $\begin{array}{l}\text { The small rivers and dams have dried up and no longer flow } \\
\text { during the dry season. }\end{array}$ \\
\hline & & Unknown insects are found in the farms. \\
\hline \multirow[t]{7}{*}{ Time reference } & \multirow[t]{7}{*}{ Reference period } & $\begin{array}{l}\text { There was no rain even in June, which is in the rainy season. } \\
\text { This year (2011) there was no rain in July either. }\end{array}$ \\
\hline & & $\begin{array}{l}\text { In July, it used to rain a lot, precisely on July 14th; now it does } \\
\text { not rain. }\end{array}$ \\
\hline & & $\begin{array}{l}\text { It used to rain in April, even until July, but now everything has } \\
\text { changed. }\end{array}$ \\
\hline & & In the past, the early yams were harvested in July. \\
\hline & & In the past, February was the beginning of the growing season. \\
\hline & & In 2006 , it did not rain much. However, in 2009 , it was worse. \\
\hline & & $\begin{array}{l}\text { In 1985, there was a major wildfire. In 1990, bush fires } \\
\text { destroyed everything. }\end{array}$ \\
\hline
\end{tabular}

Focus Groups 
Table 5 Description of farmers' perception of climate change through non-climatic indicators in Korhogo

\begin{tabular}{|c|c|c|}
\hline Level & Sub-level & Description \\
\hline \multirow[t]{3}{*}{ Agriculture } & \multirow[t]{3}{*}{ Farming seasons } & $\begin{array}{l}\text { The farming seasons were longer before, and there were two- or } \\
\text { three-month intervals between two rainy seasons }\end{array}$ \\
\hline & & $\begin{array}{l}\text { In the past, the first rains were strong and followed by the sun. } \\
\text { They were called "Gbinwoza" or "Zewoza" which means "rain } \\
\text { of February" in Sénoufo, the local language of Korhogo. }\end{array}$ \\
\hline & & $\begin{array}{l}\text { January and February were characterized by hot winds that predict } \\
\text { the coming rains; however, now the rain begins in May and ends } \\
\text { in September. }\end{array}$ \\
\hline
\end{tabular}

Farming practices There is a disturbance in the agricultural calendar. The former planting dates are not anymore suitable to the new climatic conditions. Indeed, it does not rain enough during the sowing time; for instance, it often happens that the rain stops when the rice is sown.

The lack of rain makes the space used for growing remain dry for a long period.

The long-season (6 months) crops of yam (Dioscorea spp.) and rice (Oryza sativa) cannot be grown anymore because of lack of rain.

Before, there were already new yams in August.

In the past, the first rains started in March and April; the fields were already cleaned, and the hillocks of yams were built up so that the yams were already mature by August. Nowadays, the yams are progressively abandoned because it does not suit the new climate.

The technique of crop succession is not feasible anymore. In the past, farmers could grow groundnuts followed by cotton; after the harvest of the groundnut, the furrows were used for the sowing of cotton.

The rice could be grown twice a year, the "SATMACI" variety during the dry season and another variety in the rainy season. But now, only one harvest a year (during rainy season) can be done if the rain does not stop.

Environment

Local environment

Time reference Reference period
Before, it rained enough and all the ponds and streams were filled. One could even see fishes. Moreover, water remained in shallow wells in dry periods. Nowadays, it completely disappears during the dry season.

If it rains today, the soil dries up faster

In the past, farmers harvested the rice and brought it to the village while it still rained, but now it stops before the harvest period.

In the past, old men forecasted well the rain based on the intensity of sunshine and the stars in the sky. Now, the sun is not anymore an indicator of rains but rather the announcement of a freshness period.

It rained a lot in August and all the roads were flooded at that time; but today, August is dry

In the past, the groundnut in some villages and the new yams were already mature in August.

The maturation time of the Shea nuts coincided with the rainfall, which does not happen anymore. 
in Toumodi. The rainy season was earlier well defined, and marked by the fruits of the Shea butter tree beginning to mature.

\subsubsection{Wind and sunshine}

The intensity of the sun and the power of winds have changed. Before, the winds were less intense, but now, strong winds which precede the rains chase out the stormy clouds. The lack of data on changes in wind speeds from SODEXAM does not help to confirm farmer's assertion. However, similar increasing winds had caused more pronounced movement of sand and destroying crops in Burkina Faso, a neighbor country of Côte d'Ivoire (Nielsen and Reenberg 2010). Sunshine is stronger nowadays than it was two decades before. For instance, from 1971 to 2000, the temperature in Korhogo has increased by an average of $0.8{ }^{\circ} \mathrm{C}$ every year (database from SODEXAM). Moreover, the direction of wind has changed according to some farmers. Further details of farmers' perception of CC are presented in Tables 4 and 5.

Table 6 Description of relevant actions implemented by farmers to deal with their threats in farm management

\begin{tabular}{|c|c|c|c|c|c|}
\hline \multirow[t]{2}{*}{ Level } & \multirow[t]{2}{*}{ Action implemented } & \multicolumn{2}{|l|}{ Toumodi } & \multicolumn{2}{|l|}{ Korhogo } \\
\hline & & Quotation & $\%$ & Quotation & $\%$ \\
\hline \multirow{9}{*}{$\begin{array}{l}\text { Farming activities } \\
\text { implementation }\end{array}$} & Association of crops & 2 & 5.26 & 0 & 0 \\
\hline & Use of new varieties & 1 & 2.63 & 0 & 0 \\
\hline & Re sowing \& re planting & 5 & 13.16 & 3 & 5.45 \\
\hline & Cleaning by hand & 3 & 7.89 & 10 & 18.18 \\
\hline & Farming activities quickly completed & 1 & 2.63 & 1 & 1.82 \\
\hline & Sanitary treatment of farms and livestock & 11 & 28.95 & 16 & 29.09 \\
\hline & Animals in pens & 3 & 7.89 & 0 & 0 \\
\hline & Firewalls & 3 & 7.89 & 0 & 0 \\
\hline & Group of mutual aid & 2 & 5.26 & 1 & 1.82 \\
\hline \multirow{5}{*}{$\begin{array}{l}\text { Funding of farming } \\
\text { activities }\end{array}$} & Borrow money to buy inputs & 0 & 0 & 1 & 1.82 \\
\hline & Funding certain product by selling others & 3 & 7.89 & 4 & 7.27 \\
\hline & Pre-financing of farming activities & 1 & 2.63 & 2 & 3.64 \\
\hline & Produce charcoal to buy inputs & 0 & 0 & 4 & 7.27 \\
\hline & Sell fertilizer to solve household problem & 0 & 0 & 1 & 1.82 \\
\hline \multirow{3}{*}{$\begin{array}{l}\text { Nature of farming } \\
\text { lands }\end{array}$} & Find new farming lands & 0 & 0 & 1 & 1.82 \\
\hline & Soil fertilization & 0 & 0 & 2 & 3.64 \\
\hline & Reducing farm size & 1 & 2.63 & 0 & 0 \\
\hline \multirow[t]{2}{*}{ Sale of products } & Creation of cooperative for better market access & 0 & 0 & 6 & 10.91 \\
\hline & Sell before harvest & 1 & 2.63 & 0 & 0 \\
\hline \multirow[t]{3}{*}{ No actions } & No solutions & 1 & 2.63 & 3 & 5.45 \\
\hline & Total & 38 & 100 & 55 & 100 \\
\hline & Standard deviation & 2.55 & 6.72 & 4.00 & 7.27 \\
\hline
\end{tabular}

Focus Groups 
4.3 Action implemented against threats in farm management

Five different levels of intervention were identified (including the option of "no action") (Table 6): Implementation of farming activities, Funding of farming activities, Sale of products, and Nature of farming lands. However, no measures for fighting against bushfires and straying of animals were mentioned in Korhogo; the farmers deal with the problem of funding agricultural activities by producing charcoal. This short-term solution is a real problem, as deforestation in this area has increased in 2002 after the departure of water and forest protection agents due to the civil war (Pswarayi et al. 2010).

Poor soils in Korhogo have resulted in the search for more suitable land for agriculture. Otherwise, fertilizers, pesticides, and herbicides are applied if farmers have adequate financial means; in addition, farmers are more likely to organize themselves into cooperatives and informal groups to facilitate the sale of their products.

4.4 Interrelationship between non-climatic threats in farm management and arising actions implemented by farmers

In Toumodi, as in Korhogo, farmers implemented more measures for farming activities (borrowing money to buy inputs, re-sowing, replanting, etc.), while threats related to damage by livestock were inadequately addressed (Fig. 3). Therefore, farmers' range of possibilities with regard to technical farming activities is more important, while the lack of technical support is not addressed at all because it is outside the farmers' field of action. Also, the centrality of "no solutions" in Fig. 2 reveals the low adaptive capacity of farmers in dealing with non-climatic threats.

\subsection{Adaptation strategies for climate change}

The variety of rice (Oryza sativa) called 'SATMACI' was grown twice a year in Korhogo, but now, due to climate variability and change, only one harvest is possible

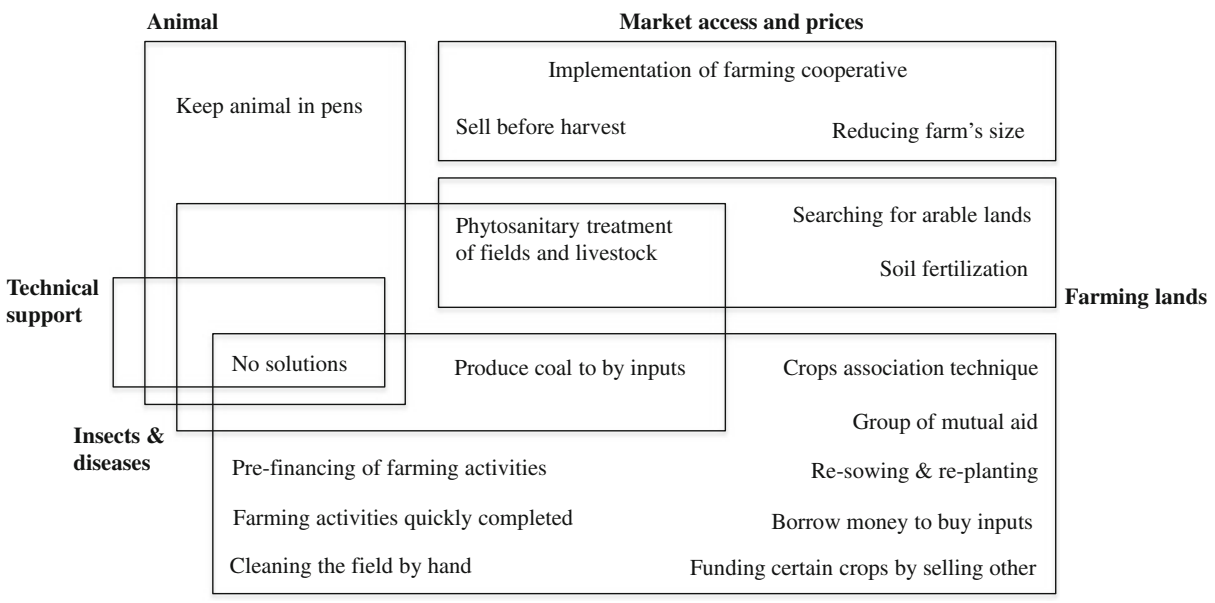

Technical farming factors

Fig. 3 Interrelationships between implemented actions and corresponding non-climatic threats in both study areas 


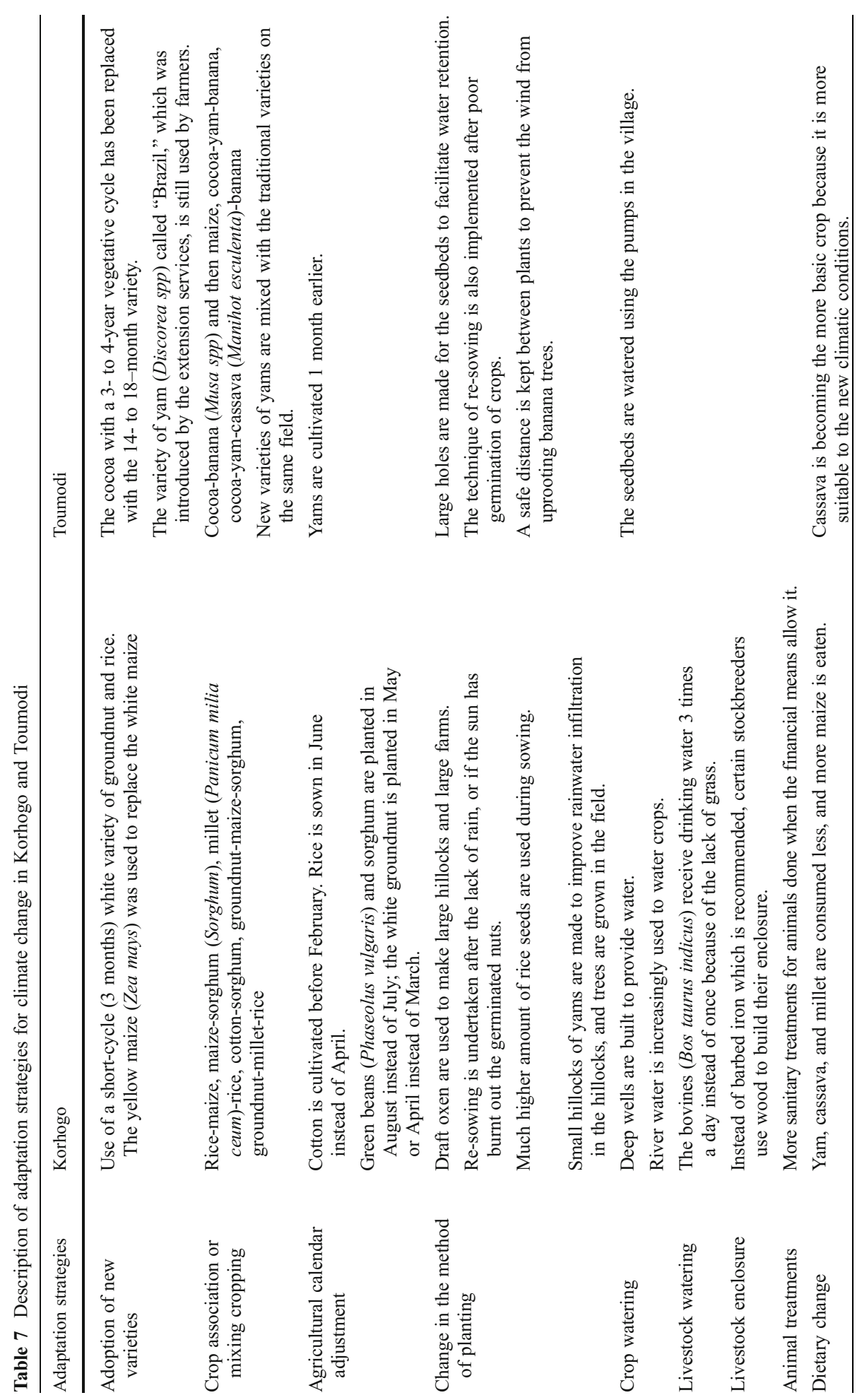




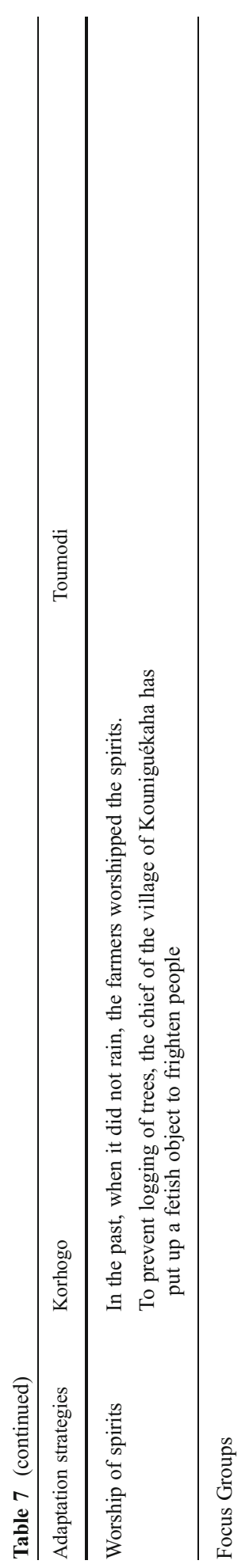




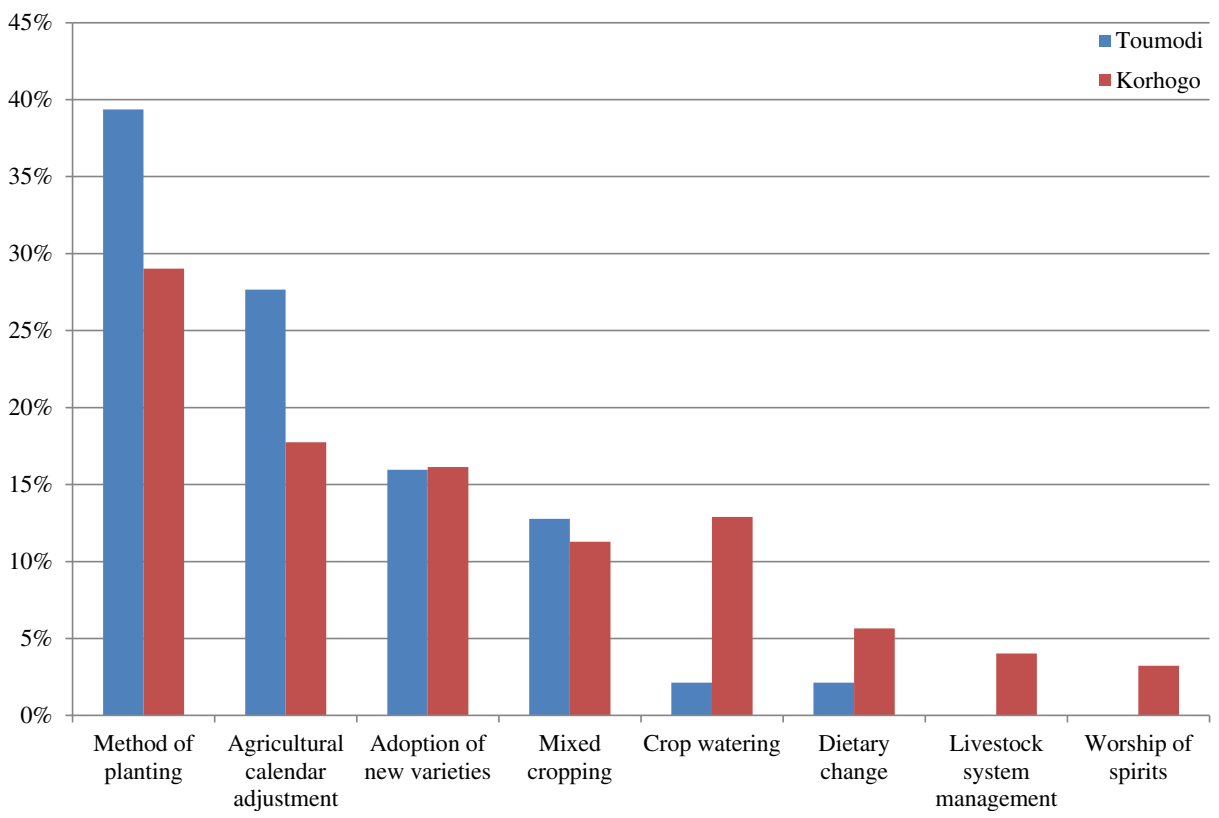

Fig. 4 Importance of adaptation strategies to climate change in Toumodi and Korhogo

per year. Moreover, in Korhogo, the cultivation of groundnuts (Arachis hypogaea) was followed by white cotton (Gossypium hirsutum). After harvesting the groundnuts, farmers used the old furrows for the sowing of cotton; but inadequate rains have prevented similar practice in recent times and the farmers needed to adapt. The adaptation strategies in both areas included other practices such as change in diet and worship of spirits (see Table 7).

The adaptation levels found using Focus Groups appear to be rather similar in Toumodi and Korhogo (Fig. 4). The most developed strategies concern the different methods of planting. This is followed in order by agricultural calendar adjustment, adoption of new varieties, and implementing mixed cropping. However, at the level of "water shortage solving," farmers in Korhogo have implemented more strategies than farmers in Toumodi, which shows the extent of water shortage problems in this zone. For certain adaptation levels such as "livestock system management," farmers in Toumodi appear to have adapted no strategies.

\subsection{Identification of factors influencing farmers' adaptation behavior}

Different influential factors were identified (Table 8). They were grouped into two levels: internal factors related to farmers and exogenous ones. Internal factors are, for instance, gender, farming experience, household size, and wealth. Exogenous factors found to be influential are, for instance, lack of contact with extension services, length of rainy seasons, and the availability of drought-resistant crop varieties. This distinction between factors has been made to help future agricultural policies to focus on identified factors to ensure implementation of climate adaptation measures. 
Table 8 Internal and external factors influencing farmers' behavior with regard to adaptation to climate change

\begin{tabular}{|c|c|c|}
\hline Type & Factor & Level \\
\hline Internal factors & $\begin{array}{l}\text { Gender } \\
\text { Experience in farming activities } \\
\text { Household size } \\
\text { Financial goals } \\
\text { Financial means } \\
\text { Failure to understand? rainfall forecasts } \\
\text { Aims to adopt the best varieties } \\
\text { Objective of early harvest } \\
\text { Type of crop in association } \\
\text { Ensure a safety production of at least one crop in association } \\
\text { Harnessed culture } \\
\text { Perceived benefits of the new technique } \\
\text { Religion }\end{array}$ & Farmer \\
\hline \multirow[t]{5}{*}{ Exogenous factors } & $\begin{array}{l}\text { Lack of contact with extension services } \\
\text { Existence of village pump } \\
\text { Price of certain products such as cotton } \\
\text { Scarcity of rains } \\
\text { Length of the rainy season } \\
\text { Beginning of the first rains } \\
\text { Stop of rains after sowing } \\
\text { High winds } \\
\text { Sunshine }\end{array}$ & Institutional \\
\hline & $\begin{array}{l}\text { Availability of farming lands } \\
\text { Soil fertility } \\
\text { Presence of trees on the field }\end{array}$ & Lands and soil \\
\hline & $\begin{array}{l}\text { High price of fertilizer, seeds, farming labor } \\
\text { Adaptation of the variety to any type of soil } \\
\text { Drought resistant variety } \\
\text { Short-season variety } \\
\text { Good production's quality of the variety }\end{array}$ & $\begin{array}{l}\text { Inputs } \\
\text { New varieties }\end{array}$ \\
\hline & $\begin{array}{l}\text { Good adequacy of corn, rice, cassava } \\
\text { Poor harvest } \\
\text { Disease of draft oxen } \\
\text { Gradual disappearance of yam and millet }\end{array}$ & Farm \\
\hline & $\begin{array}{l}\text { Crop water requirement } \\
\text { Availability of wood to build up animal fence } \\
\text { Lack of pasture } \\
\text { Draining of the wells } \\
\text { Existence of nearby rivers or dams }\end{array}$ & Environmental \\
\hline
\end{tabular}

Focus Groups 


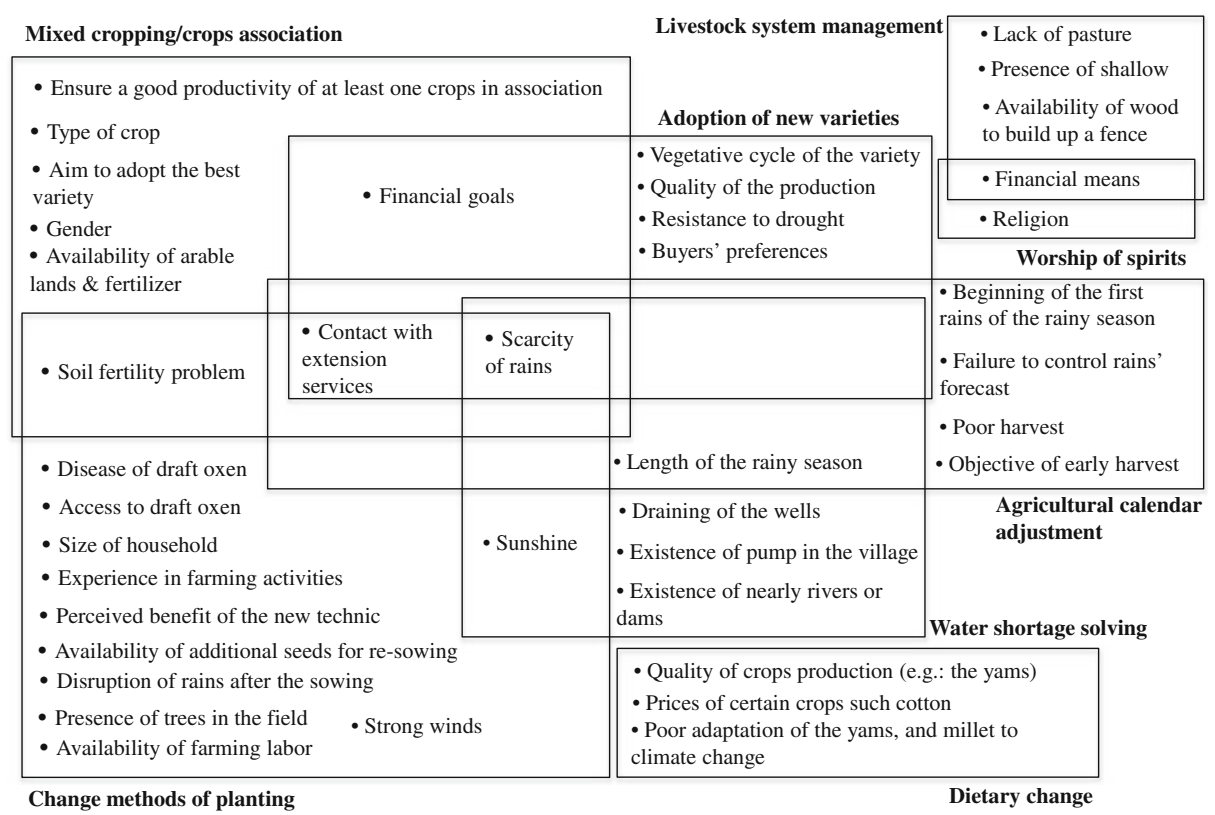

Fig. 5 Interrelationships between influencing factors and adaptation strategies to climate change

\subsection{Interrelationship between influencing factors and adaptation strategies}

The interrelationships between identified factors and different adaptation strategies are shown in Fig. 5. Different factors affecting farmers' behavior are identified and then linked to a specific adaptation measure. Therefore, some factors influence different levels of adaptation at the same time, which reflect their relative importance. Scarcity of rains and the lack of contact with extension services are the factors which influence the most adaptation strategies, followed by sunshine and financial goals. The probable interaction between different levels of adaptation cannot be excluded, but in Fig. 5, only the interrelationships between factors and adaptation levels have been highlighted. Furthermore, change in the method of planting and mixed cropping/crop associations are the adaptation strategies related with the largest number of factors.

\section{Conclusion}

$\mathrm{CC}$ emerged as a significant constraint for poor smallholder farmers in terms of satisfying their food needs; the present study therefore has gathered in-depth information to better understand farmers' adaptation behavior. This research thus forms the basis and contextual background for subsequent quantitative analyses on the adaptation behavior of farmers in Côte d'Ivoire. Therefore, the identified local strategies need to be enhanced by researchers. We suggest that future agricultural policies take into account farmers' perception, to provide suitable climate forecast and to improve local technical support for better adaptation to climate change, and to ensure successful knowledge transfer in the local framework.

Our analysis reveals that smallholder farmers in Toumodi and Korhogo (Côte d'Ivoire) perceive, in addition to problems related to insects and diseases, market access, prices, and 
changes in climatic conditions to be relevant constraints for their farming activities. To address these threats, four different levels of intervention were identified: Farming activities implementation, Funding of farming activities, Sale of products, and Nature of farming lands. Adaptation measures related to the first category were the most implemented and comprise, for instance, crop associations and re-sowing and replanting. The study also revealed the low adaptive capacity of farmers to deal with non-climatic threats because of a lack of technical support, which falls outside of their decision-making ability. Farmers strongly perceive $\mathrm{CC}$ through characteristics and changes in rain patterns, changes in the local environment, and the disappearance of certain farming practices. Farmers in Toumodi perceive more the impacts of CC through the disruption of key time reference period and shift in rainy seasons, than farmers in Korhogo. To adapt, they mostly change the methods of planting, adjust the agricultural calendar, adopt new varieties, and employ mixed cropping. This adaptation behavior is influenced by the factors "contact with extension services" and "scarcity of rains." Furthermore, farmers in both study areas asserted that they have no effective solutions to adopt when facing poor seed quality, strong sunshine, and new weed varieties.

Furthermore, based on our results, we suggest that for better adaptation to climate change in Côte d'Ivoire, future agricultural policies should take into account farmers' perception, to provide suitable climate forecast and to improve local technical support. Local organizations and non-governmental organization (NGOs) need to work together on government extension services and also try to involve a greater number of farmers in the services and ensure proper transfer of adaptation measures.

Acknowledgments The authors would like to acknowledge the North-south Centre of ETH Zurich (now ETH Global) in providing a fellowship to the first author for doctoral study at the Swiss Federal Institute of Technology Zurich, Switzerland.

\section{References}

Beaudou AG, Sayol R (1980) Étude Pédologique de la Région de Boundiali-Korhogo (Côte-d'Ivoire). Cartographie et Typologie Sommaire des Sols, Feuille Boundiali, Feuille Korhogo, 1/200.000. Notice Explicative no. 84. Office de la Recherche Scientifique et Technique Outre-Mer (ORSTOM), Paris, pp 1-49

Benedicta Y, Paul LG, Manschadi AM (2010) Farmers' perception and adaptation to climate change; A case study of sekyedumase district in Ghana. Paper presented at the Tropentag, ETH Zurich, Zürich, 14-16 September 2010

Birgit H, Bruzon V (2006) Profil Environnemental de la Côte d'Ivoire. Rapport Final. Consortium AGRIFOR Consult. Côte d'Ivoire

Blennow K, Persson J (2009) Climate change: motivation for taking measure to adapt. Glob Environ Chang 19(1):100-104

Boko M, Niang I, Nyong A et al (2007) In: Parry ML, Canziani OF, Palutikof JP, van der Linden PJ, Hanson CE (eds) Climate change 2007: impacts, adaptation and vulnerability. Contribution of working group II to the fourth assessment report of the intergovernmental panel on climate change. Cambridge University Press, Cambridge, pp 433-467

Chappell A, Agnew CT (2004) Modelling west African Sahel rainfall (1931-1990) as an artifact of changing station networks. Int J Climatol 24(5):547-554

Collier P, Conway G, Venables T (2008) Climate change and Africa. Oxford Rev Econ Policy 24(2):337-353

MEEF (Ministère de l'Environnement de l'Eau et de la Forêt) (2000) Communication nationale de la Côte d'Ivoire. Préparée en application de la Convention Cadre des Nations Unies sur les changements climatiques. Bureau du Projet Changements Climatiques. Côte d'Ivoire

De Wit M (2006) Climate change and African agriculture. Policy Note No. 10. CEEPA, based on Maddison (2006). The perception of and adaptation to climate change in Africa. CEEPA Discussion Paper No.10, CEEPA, University of Pretoria, Pretoria

Dixon RK, Smith J, Guill S (2003) Life on the edge: vulnerability and adaptation of African ecosystems to global climate change. Mitig Adapt Strateg Glob Change 8(2):93-113 
MET (Ministère de l'Environnement et du Tourisme) (1994) Livre Blanc de l'Environnement de Côte d'Ivoire, Tome 1. Ministère de l'Environnement et du Tourisme, Côte d'Ivoire

Elke UW (2010) What shapes perceptions of climate change? WIREs Clim Chang 1(3):332-342

Field A (ed) (2009) Discovering statistics using SPSS. Sage Publications, London

Gadegbeku S (2009) Communication within the workshop for the beginning of the project "An ecosystems approach to managing water and health in the context of Climate Change: adaptive strategies to drought and flooding in four West African countries: Côte d'Ivoire, Togo, Mauritania and Senegal". June 9th 2009, Korhogo, Centre Suisse de Recherches Scientifiques (CSRS). Côte d'Ivoire

Goula BT, Srohourou B, Brida A et al (2010) Determination and variability of growing seasons in Côte d'Ivoire. Int J Eng Sci 2(11):5993-6003

Hussein K, Sumberg J, Seddon D (1999) Increasing violent conflict between Herders and farmers in Africa: claims and evidence. Dev Pol Rev 17:397-418

IPCC (2007) Summary for policymakers. In: Parry ML, Canziani OF, Palutikof JP, van der Linden PJ, Hanson CE (eds) Climate change 2007: impacts, adaptation and vulnerability. Contribution of working group II to the fourth assessment report of the intergovernmental panel on climate change. Cambridge University Press, Cambridge, pp 7-22

Ishak N, Bakar A (2012) Qualitative data management and analysis using NVivo: an approach used to examine leadership qualities among student leaders. Educ Res J 2(3):94-103

Kouakou K, Goula Bi, Kouassi A (2012) Analyze of climate variability and change impacts on hydro-climate parameters: case study of Côte d'Ivoire. Int J Sci Eng Res 3(2):1-8

Krueger RA (ed) (1994) Focus groups: a practical guide for applied research. Sage Publications, Thousand Oaks, California

Maddison D (2006) The perception of and adaptation to climate change in Africa. CEEPA Discussion Paper No. 10. Centre for Environmental Economics and Policy in Africa, University of Pretoria. South Africa

Mendelsohn R, Dinar A, Dalfelt A (2000) Climate change impacts on African agriculture. World Bank, Washington DC

Morgan DL (ed) (1997) Focus groups as qualitative research. In: Qualitative research methods series vol. 16. Sage, London

Morgan DL, Krueger RA (eds) (1998) The focus group kit. Sage Publications, Thousand Oaks, California

Nicholson SE (2000) The nature of rainfall variability over Africa on time scales of decades to millennia. Glob Planet Chang 26:137-158

Nielsen JØ, Reenberg A (2010) Cultural barriers to climate change adaptation: a case study from Northern Burkina Faso. Glob Environ Chang 20:142-152

Ochou A (2011) Réchauffement Climatique: Origines, Manifestations et Impacts. Communication. Ministère de l'Environnement et du Développement Durable. République de Côte d'Ivoire

Paillé P (1996) De l'analyse qualitative en général et de l'analyse thématique en particulier. Rech Qualitatives 15:179-194

Pswarayi R, Olojoba A, Thadden S et al (2010) Côte d'Ivoire. Analyse Environnementale Pays. Banque Mondiale. Rapport basé sur les travaux de recherche de la Société Française de Réalisation, d'Études et de Conseil (SOFRECO) sur l'impact du conflit sur la forêt et les ressources pendant le processus de réunification et de reconstruction. Rapport final. Banque Mondiale

Rabiee F (2004) Focus-group interview and data analysis. Proc Nutr Soc 63:655-660

MPARH (Ministère de la Production Animale et des Ressources Halieutiques) (2003) Rapport national sur l'état des ressources zoogénétiques. République de Côte d'Ivoire.

Ringler C (2010) Climate change and hunger: Africa's smallholder farmers struggle to adapt. The agricultural economics society and the European association of agricultural economists. EuroChoices 9(3):16-21

Ritchie J, Spencer L (1994) Qualitative data analysis for applied policy research. In: Bryman A, Burgess RG (eds) Analysing qualitative data. Routledge, London, pp 173-194

Templeton JF (1994) The focus group: a strategic guide to organizing, conducting, and analyzing the focus group interview. Revised edition. Probus Publishing Co., Chicago

Tié B, Diby L, Seyo E et al (2010) Estimating soil available nitrogen with a hot H2O2/KCl extraction. Sci Res Essays 5(12):1455-1462

Washington R, Harrison M, Conway D et al (2006) African climate change - taking the shorter route. B Am Meteorol Soc 87:1355-1366

Wittig R, König K, Schmidt M et al (2007) A study of climate change and anthropogenic impacts in West Africa. Environ Sci Pollut Res 14(3):182-189

Zagbaï S, Berti F, Lebailly P (2006) Impact de la dynamique cotonnière sur le développement rural. Étude de cas de la région de Korhogo, au Nord et au Centre de la Côte d'Ivoire. Biotechnol Agron Soc Environ 10 (4):325-334

Zaouche M, Schaer B, Bauer C (2011) Training focus groups. Focus Balkans, GEM, Ecozept. Balkans 